\title{
Soil seed bank dynamics in Tithonia diversifolia dominated fallowland at Ile- Ife, South-western Nigeria
}

\author{
Samson Olajide OKE *, Olaniran Temitope OLADIPO, Charlotte Chibuzor \\ NDIRIBE, Damilare Stephen AKINYEMI and Olubukola Modupe OJO \\ Department of Botany, Obafemi Awolowo University, Ile-Ife, Nigeria. \\ *Corresponding author, E-mail: soke@oauife.edu.ng
}

\begin{abstract}
The soil seed bank of Tithonia diversifolia, an invasive species which dominates open waste fallowland vegetation was studied. Two different roadside sites which vary in extent of open waste land were selected. The species composition of the established vegetation was assessed in the two different sites. Twenty top soil samples were collected at 0-15 cm five different distances $(15 \mathrm{~m}, 30 \mathrm{~m}, 45 \mathrm{~m}, 60 \mathrm{~m}$, and $75 \mathrm{~m})$ inwards away from each main road in dry and rainy seasons and the seed bank composition was determined by greenhouse germination over a 6 month period. The similarity between the composition of the seed bank flora and that of the established vegetation was low. The least and the highest emerged seedlings density were recorded in the $15 \mathrm{~m}$ and $75 \mathrm{~m}$ respectively inwards away from the main road in both seasons. The results of the seedlings emergence are a reflection of the extent of open waste land dominated by the invasive species due to human disturbance (road construction) on both sites. Overall results suggest that the emergence of the species from the soil seed bank may be due to the impact of the invasive species - Tithonia diversifolia on other plant species in the study environment.

(C) 2009 International Formulae Group. All rights reserved.
\end{abstract}

Keywords: Fallowland, invasive species, seedling emergence, seed bank.

\section{INTRODUCTION}

The introduction of plant species into a new environment deliberately or otherwise can have many unanticipated ecological effects (Howard and Hartemink, 2000). These introduced species otherwise called invasive species can have devastating effects on ecosystem quality and functioning as they often time out-compete indigenous or native species thereby leading to the extinction or disappearance of an endemic species (Lorence and Suesman, 1986). The threat to biodiversity due to invasive alien species is considered second only to that of habitat destruction. Invasive species cause loss of biodiversity including species extinction, and changes in hydrology and ecosystem function (Raghubanshi et al., 2005). Thus, invasive species are a serious threat to conservation and sustainable use of biodiversity with undesirable impacts on the services provided by the ecosystem (Raghubanshi et al., 2005). Invasive plant species such as Tithonia diversifolia have been shown to impede both ecological and conservation studies (Adebowale and Olorode, 2005). The mechanism by which invasive species affect native communities may include competition, altered ecosystem processes or other pathways like allelopathy or phytotoxicity (Samuel et al., 2005). Invasive species have been reported to affect seedlings emergence of native species to varying degree (Samuel et al., 2005). Similarly, Samuel et al. (2005) reported that extracts from parts of certain invasive species affected seedling emergence 
time, leaf biomass of native tree seedlings to varying degrees in the native species.

In Nigeria, especially in the lowland rainforest as well as in other habitats, these exotic/alien species especially Tithonia diversifolia now dominate a sizeable portion of the secondary fallow vegetation. Invasive species cause a reduction in native biodiversity through negative effect on the recruitment and persistence of native plant species (Pagad and Browne, 2008). They tend to be highly successful as judged, in part by their ability to produce abundance of seeds that, in some cases, may live long in the soil seed bank. The invasion of the tropical rainforest landscape of Nigeria by Tithonia diversifolia is generating a lot of concern in view of its aggressive growth rate, heavy seed production and allelopathy. Hence, the presence of a seed bank in the soil may be of prime importance in the context of plant communities restoration (Bisteau and Mahy 2005). Habitat restoration, which aims at developing functional ecological networks is a very sensitive topic for tropical disturbed habitats.

In this work, we focused our efforts on the role of Tithonia diversifolia in secondary fallowland vegetation dynamics and on the potential of the community to regenerate from soil seed bank. The aims of this study were to: (1) determine the density and dynamics of germinable/live seeds in the soil seed bank of secondary fallowland of Tithonia diversifolia dominated environment in relation to season. (2) assess the relationship between the composition of the established vegetation and the seed bank (3) determine the effect of extent of disturbed/fallowland due to human activities such as road construction colonised by Tithonia diversifolia on seedling emergence in the study sites.

\section{MATERIALS AND METHODS}

The study sites are the secondary fallowland vegetations (due to human disturbance by road construction) dominated by Tithonia diversifolia along Ife - Ibadan dual carriage way $\left(07^{\circ} 29.919^{\prime} \mathrm{N}\right.$; $\left.004^{\circ} 26.871^{\prime} \mathrm{E}\right)$ and Ife - Ilesa single lane highway $\left(07^{\circ} 31.866^{\prime} \mathrm{N}\right.$; $\left.004^{\circ} 34.424^{\prime} \mathrm{E}\right)$ in IleIfe area of South-western Nigeria. The study was carried out between 2006 and 2007. The mean annual rainfall of $1400 \mathrm{~mm}$ (five year mean) has been reported for Ile-Ife (Oke and Isichei, 1997). The soils of the study sites have been classified as Iwo series (Smyth and Montgomery, 1962) while the vegetation is lowland rainforest. In each of the two study sites, soil samples were collected in two occasions, before and during rainy season, i.e. March and July 2006 respectively. Soil samples were taken, using soil auger (diameter $8.5 \mathrm{~cm}$ ) at a depth of $0-15 \mathrm{~cm}$. The soil samples were randomly collected from distances, 15, 40, 45, 60 and $75 \mathrm{~m}$ inward away from the roadside to the forest edge across the secondary fallowland vegetation. The soil samples were then packed, labelled and transferred to the laboratory at the Department of Botany, Obafemi Awolowo University, Ile-Ife, Nigeria, where they were spread in the laboratory tables and air-dried.

The soil samples were put in containers for seeds germination under nursery conditions. Germinated seeds were observed, identified and counted daily up to six months. Emerged seedlings were identified as trees/shrubs, herbs and grasses. The seedlings were removed after counting and identification to facilitate further germination and counting. The identification followed Hutchinson and Dalziel (1954-72) Flora of west tropical Africa. Unidentified seedlings that were required for correct identification were uprooted and transplanted into bigger pots until proper identification could be carried out at IFE Herbarium. Number of emerged seedlings was obtained in each site and season. The percentage contribution of each species to the soil seed bank was also determined seasonally. Sorenson Similarity index (Sorenson, 1948) was also used to compare the similarity in species composition (standing vegetation and seed bank) among the two study sites. A two-way Analysis of Variance (ANOVA) was used to compare the soil seed bank density per site for the two seasons.

\section{RESULTS}

\section{Species composition of the standing vegetation}

The standing vegetation species composition of the two study sites is presented in Table 1. Thirty-two (32) plant species 
Table 1: Plant species composition of the standing vegetation of the study plots.

\begin{tabular}{|c|c|c|c|}
\hline Species & Family & Site 1 & Site 2 \\
\hline Andropogon gayanus & Poaceae & + & + \\
\hline Aspilia helianthus & Asteraceae & + & - \\
\hline Bracharia deflexa & Poaceae & + & + \\
\hline Cassia hirsuta & Caesalpiniaceae & + & - \\
\hline Chromolaena odorata & Asteraceae & + & - \\
\hline Cnetis feruginea & Connaraceae & - & + \\
\hline Combretum platypterum & Combretaceae & - & + \\
\hline Deinbollia pinnata & Sapindaceae & - & + \\
\hline Desmodium scorparius & Fabaceae & + & + \\
\hline Euphorbia heterophylla & Euphorbiaceae & + & _ \\
\hline Euphorbia hirta & Euphorbiaceae & + & - \\
\hline Ficus exasperata & Moraceae & - & + \\
\hline Icacina trichantha & Icacinaceae & - & + \\
\hline Indigofera pulcra & Papilionaceae & + & - \\
\hline Ipomea involucrata & Convolvulaceae & - & + \\
\hline Mallotus oppositifolium & Euphorbiaceae & + & - \\
\hline Mimosa pudica & Mimosaceae & + & - \\
\hline Mucuna pruriens & Papilionaceae & - & + \\
\hline Newbouldia laevis & Bignoniaceae & + & _ \\
\hline Pandiaca spp & Amaranthaceae & + & - \\
\hline Panicum maximum & Poaceae & - & + \\
\hline Phyllanthus amarus & Euphorbiaceae & + & + \\
\hline Salacia celastraceae & Celastraceae & - & + \\
\hline Sida acuta & Malvaceae & + & + \\
\hline Spigelia anthelmia & Loganiaceae & + & + \\
\hline Spondia mombin & Anarcadiaceae & + & - \\
\hline Talinum trangulare & Portulacaceae & + & - \\
\hline Tephrosia bracteolata & Papilionaceae & + & - \\
\hline Trema orientalis & Ulmaceae & + & + \\
\hline Trianthema portulacastrum & Aizoaceae & + & - \\
\hline Tridax procumbens & Asteraceae & + & - \\
\hline Tithonia rotundifolia & Asteraceae & + & - \\
\hline
\end{tabular}

belonging to 22 families were encountered in the standing vegetation in the two sites and the species were predominantly shrubs and herbaceous species. The list also reveals the presence of nine (9) woody species $(28.1 \%)$, three (3) grass species $(9.4 \%)$ and twenty herbaceous species (62.5\%). A low level of similarity $(40 \%)$ exists between the standing vegetation of the two study sites using similarity analysis (Sorenson 1948). The eight (8) common plant species in the standing vegetation at the two study sites were: Andropogon tectorum, Bracharia deflexa, Desmodium scorparius, Phyllantus amarus, Sida acuta, Spigellia anthelmia, Trema orientalis and Tithonia diversifolia.

\section{Species richness and density of soil seed bank}

The species composition of the soil seed bank of the two study sites is presented in Table 2. In the study site 1 (Ife-Ibadan 
S. O. OKE et al. / Int. J. Biol. Chem. Sci. 3(5): 899-911, 2009

Table 2: Density of species (seedlings $/ \mathrm{cm}^{2}$ and seeds $/ \mathrm{m}^{2}$ ) that emerged from soil collection in the two study plots in both seasons (Rainy and Dry seasons).

\begin{tabular}{|c|c|c|c|c|c|c|c|c|c|c|c|c|c|}
\hline \multirow{3}{*}{$\mathbf{S} / \mathbf{N}$} & \multirow{3}{*}{ Species } & \multicolumn{6}{|c|}{ SITE 1} & \multicolumn{6}{|c|}{ SITE 2} \\
\hline & & \multicolumn{3}{|c|}{ Rainy season } & \multicolumn{3}{|c|}{ Dry season } & \multicolumn{3}{|c|}{ Rainy season } & \multicolumn{3}{|c|}{ Dry season } \\
\hline & & $\mathrm{s} / \mathrm{cm}^{2}$ & $\mathrm{~s} / \mathrm{m}^{2}$ & $\% \mathrm{C.S}$ & $\mathrm{s} / \mathrm{cm}^{2}$ & $\mathrm{~s} / \mathrm{m}^{2}$ & $\begin{array}{l}\% \\
\text { C.S }\end{array}$ & $\mathrm{s} / \mathrm{cm}^{2}$ & $\mathrm{~s} / \mathrm{m}^{2}$ & $\begin{array}{l}\% \\
\text { C.S }\end{array}$ & $\mathrm{s} / \mathrm{cm}^{2}$ & $\mathrm{~s} / \mathrm{m}^{2}$ & $\begin{array}{l}\% \\
\text { C.S }\end{array}$ \\
\hline 1 & $\begin{array}{l}\text { Ageratum } \\
\text { conyzoides }\end{array}$ & 1 & 18 & 0.3 & 1 & 18 & 0.1 & 1 & 18 & 0.3 & 13 & 229 & 0.8 \\
\hline 2 & $\begin{array}{l}\text { Andropogon } \\
\text { gayanus }\end{array}$ & 5 & 88 & 1.4 & 5 & 88 & 0.6 & 5 & 88 & 1.6 & 11 & 194 & 0.7 \\
\hline 3 & $\begin{array}{l}\text { Andropogon } \\
\text { tectorum }\end{array}$ & 3 & 53 & 0.8 & - & - & - & 5 & 88 & 1.6 & - & - & - \\
\hline 4 & Aspilia helianthus & - & - & - & 2 & 35 & 0.2 & - & - & - & - & - & - \\
\hline 5 & $\begin{array}{l}\text { Bracharia } \\
\text { deflexa }\end{array}$ & 34 & 599 & 9.5 & 187 & 3295 & 20.8 & 138 & 2432 & 44.4 & 429 & 7559 & 27.9 \\
\hline 6 & Celosia trygnia & 5 & 88 & 1.4 & 3 & 53 & 03 & - & - & - & - & - & - \\
\hline 7 & $\begin{array}{l}\text { Ceraptopteris } \\
\text { cornuta }\end{array}$ & 1 & 18 & 03 & 2 & 35 & 0.2 & - & - & - & 1 & 18 & 0.1 \\
\hline 8 & $\begin{array}{l}\text { Chromolaena } \\
\text { odorata }\end{array}$ & 22 & 388 & 6.1 & 17 & 300 & 1.9 & 42 & 740 & 13.5 & 388 & 6837 & 25.2 \\
\hline 9 & $\begin{array}{l}\text { Desmodium } \\
\text { scorparius }\end{array}$ & - & - & - & 7 & 123 & 0.8 & - & - & - & 8 & 141 & 0.5 \\
\hline 10 & Diodia scandens & 1 & 18 & 0.3 & 4 & 70 & 0.4 & 15 & 264 & 4.8 & 146 & 2573 & 9.5 \\
\hline 11 & $\begin{array}{l}\text { Euphorbia } \\
\text { heterophylla }\end{array}$ & 25 & 441 & 7.0 & 1 & 18 & 0.1 & & & & 3 & 53 & 0.2 \\
\hline 12 & Euphorbia hirta & 4 & 70 & 1.1 & 5 & 88 & 0.6 & 1 & 18 & 0.3 & - & - & - \\
\hline
\end{tabular}


S. O. OKE et al. / Int. J. Biol. Chem. Sci. 3(5): 899-911, 2009

\begin{tabular}{|c|c|c|c|c|c|c|c|c|c|c|c|c|c|}
\hline 13 & $\begin{array}{l}\text { Euphorbia } \\
\text { hyssopifolia }\end{array}$ & - & - & - & 14 & 247 & 1.6 & - & - & - & - & - & - \\
\hline 14 & Ipomea triloba & 1 & 18 & 0.3 & - & - & - & - & - & - & - & - & - \\
\hline 15 & $\begin{array}{l}\text { Ipomea } \\
\text { involucrata }\end{array}$ & - & - & - & - & - & - & - & - & - & 1 & 18 & 0.1 \\
\hline 16 & Lantana camara & 10 & 176 & 2.8 & 3 & 53 & 0.3 & - & - & - & 24 & 423 & 1.6 \\
\hline 17 & $\begin{array}{l}\text { Laportea } \\
\text { aestuans }\end{array}$ & 8 & 141 & 2.2 & 4 & 70 & 0.4 & 1 & 18 & 0.3 & 1 & 18 & 0.1 \\
\hline 18 & $\begin{array}{l}\text { Lindernia } \\
\text { crisstacea }\end{array}$ & - & - & - & - & - & - & - & - & - & 13 & 229 & 0.8 \\
\hline 19 & Mimosa pudica & 1 & 18 & 0.3 & 3 & 53 & 0.3 & - & - & - & - & - & - \\
\hline 20 & $\begin{array}{l}\text { Oldenlandia } \\
\text { corymbosa }\end{array}$ & 60 & 1057 & 16.7 & 276 & 4863 & 30.7 & 31 & 546 & 10.0 & 294 & 5181 & 19.1 \\
\hline 21 & $\begin{array}{l}\text { Oxalis } \\
\text { corniculata }\end{array}$ & - & - & - & - & - & - & - & - & - & 3 & 53 & 0.2 \\
\hline 22 & Paulinia pinnata & 1 & 18 & 0.3 & - & - & - & - & - & - & - & - & - \\
\hline 23 & $\begin{array}{l}\text { Peperomia } \\
\text { pellucida }\end{array}$ & 2 & 35 & 0.6 & 5 & 88 & 0.6 & 10 & 176 & 3.2 & - & - & - \\
\hline 24 & Perotis indica & - & - & - & 2 & 35 & 0.2 & - & - & - & - & - & - \\
\hline 25 & $\begin{array}{l}\text { Phyllanthus } \\
\text { amarus }\end{array}$ & 2 & 35 & 0.6 & 29 & 511 & 3.2 & 4 & 70 & 1.3 & 22 & 388 & 1.4 \\
\hline 26 & $\begin{array}{l}\text { Physalis } \\
\text { anguculata }\end{array}$ & - & - & - & 1 & 18 & 0.1 & 1 & 18 & 0.3 & - & - & - \\
\hline 27 & $\begin{array}{l}\text { Portulaca } \\
\text { oleracea }\end{array}$ & 7 & 123 & 2.0 & 13 & 229 & 1.4 & - & - & - & 6 & 106 & 0.4 \\
\hline 28 & Securinega virosa & - & - & - & - & - & - & 1 & 18 & 0.3 & - & - & - \\
\hline
\end{tabular}


S. O. OKE et al. / Int. J. Biol. Chem. Sci. 3(5): 899-911, 2009

\begin{tabular}{|c|c|c|c|c|c|c|c|c|c|c|c|c|c|}
\hline 29 & Sida veronicifolia & - & - & - & - & - & - & 1 & 18 & 0.3 & - & - & - \\
\hline 30 & $\begin{array}{l}\text { Spigelia } \\
\text { anthelmia }\end{array}$ & 5 & 88 & 1.4 & 18 & 317 & 2.0 & 10 & 176 & 3.2 & 127 & 2238 & 8.3 \\
\hline 31 & $\begin{array}{l}\text { Talinum } \\
\text { triangulare }\end{array}$ & 51 & 899 & 14.2 & 81 & 1427 & 9.0 & - & - & - & 7 & 123 & 8.3 \\
\hline 32 & $\begin{array}{l}\text { Tithonia } \\
\text { diversifolia }\end{array}$ & 87 & 1533 & 24.2 & 193 & 3401 & 21.4 & 24 & 423 & 7.7 & 25 & 441 & 1.6 \\
\hline 33 & $\begin{array}{l}\text { Trianthema } \\
\text { portulacastrum }\end{array}$ & - & - & - & 15 & 264 & 17 & - & - & - & - & - & - \\
\hline 34 & Trema orientalis & 1 & 18 & 0.3 & - & - & - & 2 & 35 & 0.6 & 1 & 18 & 0.1 \\
\hline 35 & Urena lobata & 1 & 18 & 0.3 & - & - & - & - & - & - & - & - & - \\
\hline 36 & Unidentified $Y$ & 4 & 70 & 1.1 & 2 & 35 & 0.2 & 17 & 300 & 5.5 & 13 & 229 & 0.8 \\
\hline \multirow[t]{2}{*}{37} & Unidentified Z & 17 & 300 & 4.7 & 5 & 88 & 0.6 & 2 & 35 & 0.6 & 1 & 18 & 0.1 \\
\hline & & 359 & 6328 & $100 \%$ & 898 & 15822 & $100 \%$ & 311 & 5481 & $100 \%$ & 1537 & 27087 & $100 \%$ \\
\hline
\end{tabular}


road), in the rainy season sampling, a total of 359 seedlings $\left(6328\right.$ seeds $/ \mathrm{m}^{2}$ ) emerged in this study site in all the periods of the germination studies (Table 2). Twenty-six (26) species emerged containing only one woody species (Trema orientalis). Tithonia diversifolia had the highest seedling density of 87 seedlings $\left(1533\right.$ seeds $\left./ \mathrm{m}^{2}\right)$ or $24.2 \%$ of the total seed density of the soil seed bank. Oldenlanda corymbosa had the second highest seedling density of 60 seedlings $\left(1057\right.$ seeds $\left./ \mathrm{m}^{2}\right)$ or $16.7 \%$ of the total seed density of the soil seed bank. Eight (8) species namely Ageratum conyzoides, Ceratropteris cornuta, Diodia scandens, Ipomoea triloba, Mimosa pudica, Paulinia pinnata, Trema orientalis and Urena lobata had only one seedling each (18 seeds $/ \mathrm{m}^{2}$ ) or $0.3 \%$ emerged from the seed bank and other species had intermediate values. Two species were the unidentified species encountered in this study site 1 .

In the dry season sampling, 898 seedlings $\left(15822 \mathrm{seeds} / \mathrm{m}^{2}\right)$ emerged in all the months of the germination studies. Twentyseven (27) species emerged from the study site 1 and only two plant species were unidentified. Oldenlandia corymbosa had the highest seedling density of 276 seedlings $\left(4863 \mathrm{seeds} / \mathrm{m}^{2}\right)$ or $30.7 \%$ of the seed density of the seed bank (Table 2). Tithonia diversifolia seedlings also featured prominently in the seed bank with 193 seedlings (3401 seeds $/ \mathrm{m}^{2}$ ) or $21.4 \%$ of the seed bank density. Species such as Ageratum conyzoides, Euphorbia heterophylla and Physalis anguculata had one seedling (18 seeds $/ \mathrm{m}^{2}$ ) each, representing $0.1 \%$ of the seed bank while other species had intermediate values.

In the study site 2 and in the dry season sampling, 1537 seedlings $\left(27087\right.$ seeds $\left./ \mathrm{m}^{2}\right)$ emerged (Table 2). A total of 22 species emerged consisting of only one woody species: Trema orientalis as well as two unidentified species. Bracharia deflexa recorded the highest seedling density of 429 $\left(7559 \mathrm{seeds} / \mathrm{m}^{2}\right)$ or $27.9 \%$ and closely followed by Chromolaena odorata 388 seedlings $\left(6837 \mathrm{seeds} / \mathrm{m}^{2}\right)$ or $25.2 \%$ of the seed bank density while five species namely Ceratopteris cornuta, Ipomoea involucrata, Laportea aestuans, Trema orientalis and one of the unidentified species had the least seedlings emergence density of one seedling $\left(18 \mathrm{seeds} / \mathrm{m}^{2}\right)$. Tithonia diversifolia also had a seedling emergence density of 25 seedlings
(441 seeds $/ \mathrm{m}^{2}$ ) or $1.6 \%$ of the seed bank density of the study site.

In the rainy season sampling, a total of 311 seedlings $\left(5481 \mathrm{seeds} / \mathrm{m}^{2}\right.$ ) emerged in the study site (Table 2) consisting of 19 species, two of which were unidentified. One woody species (Trema orientalis) emerged in this soil sample. Bracharia deflexa had the highest seedling density of 138 or 2432 seeds $/ \mathrm{m}^{2}$ representing $44.4 \%$ of the total density of the seed bank. Chromolaena odorata recorded the second highest seedling density with 42 seedlings $\left(740 \mathrm{seeds} / \mathrm{m}^{2}\right)$ or $13.5 \%$ of the seed bank density. Tithonia diversifolia contributed 24 seedlings $\left(423\right.$ seeds $/ \mathrm{m}^{2}$ ) or $7.7 \%$ of the seed bank density. However, six (6) species: Ageratum conyzoides, Euphorbia hirta, Laportea aestuans, Physalis anguculata, Securinega virosa and Sida veronicifolia had the least seedling density of one (01) or 18 seeds $/ \mathrm{m}^{2}$ each emerged from the seed bank while the other species had intermediate values.

The monthly seedlings emergence density in the dry season soil sample revealed that site 2 (Ife-Ilesa single lane) consistently had higher values than site 1 (Ife-Ibadan dual carriage way), but this difference is not significant (Figure 1). In the rainy season, the same trend was observed (Figure 2). Comparison of seasonal seedlings emergence in the two study sites revealed that the soil sample of dry season had significantly $(\mathrm{P}<0.05)$ higher number of emerged species in both study sites than that of rainy seasons (Table 2).

\section{Seed bank and standing vegetation}

The comparison of the species composition of seed bank and the standing vegetation revealed that in the study site 1 in the dry season samples, 13 species in the seed bank had representatives in the standing vegetation (41.9\%) (Table 3). The species common to both the seed bank and the standing vegetation were: Andropogon gayanus, Aspilia helianthus, Bracharia deflexa, Chromolaena odorata, Desmodium scorparius, Euphorbia heterophylla, Euphorbia hirta, Mimosa pudica, Phyllantus amarus, Spigella anthelmia, Talinum triangulare and Trianthema portulacastrum, with Tithonia diversifolia being the dominant species. 
S. O. OKE et al. / Int. J. Biol. Chem. Sci. 3(5): 899-911, 2009

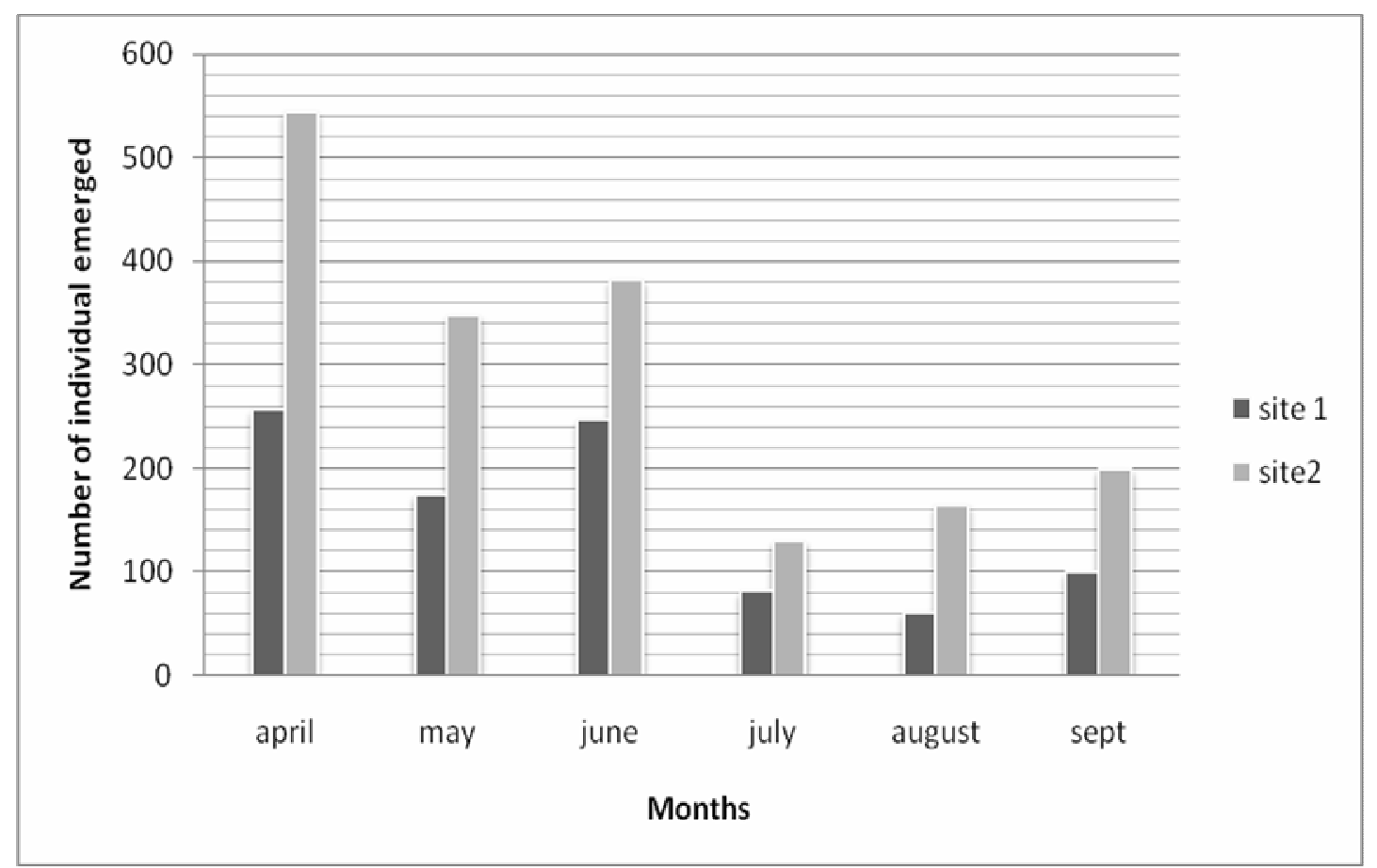

Figure 1: Monthly seedling emergence densities in the dry season in sites 1 and 2.

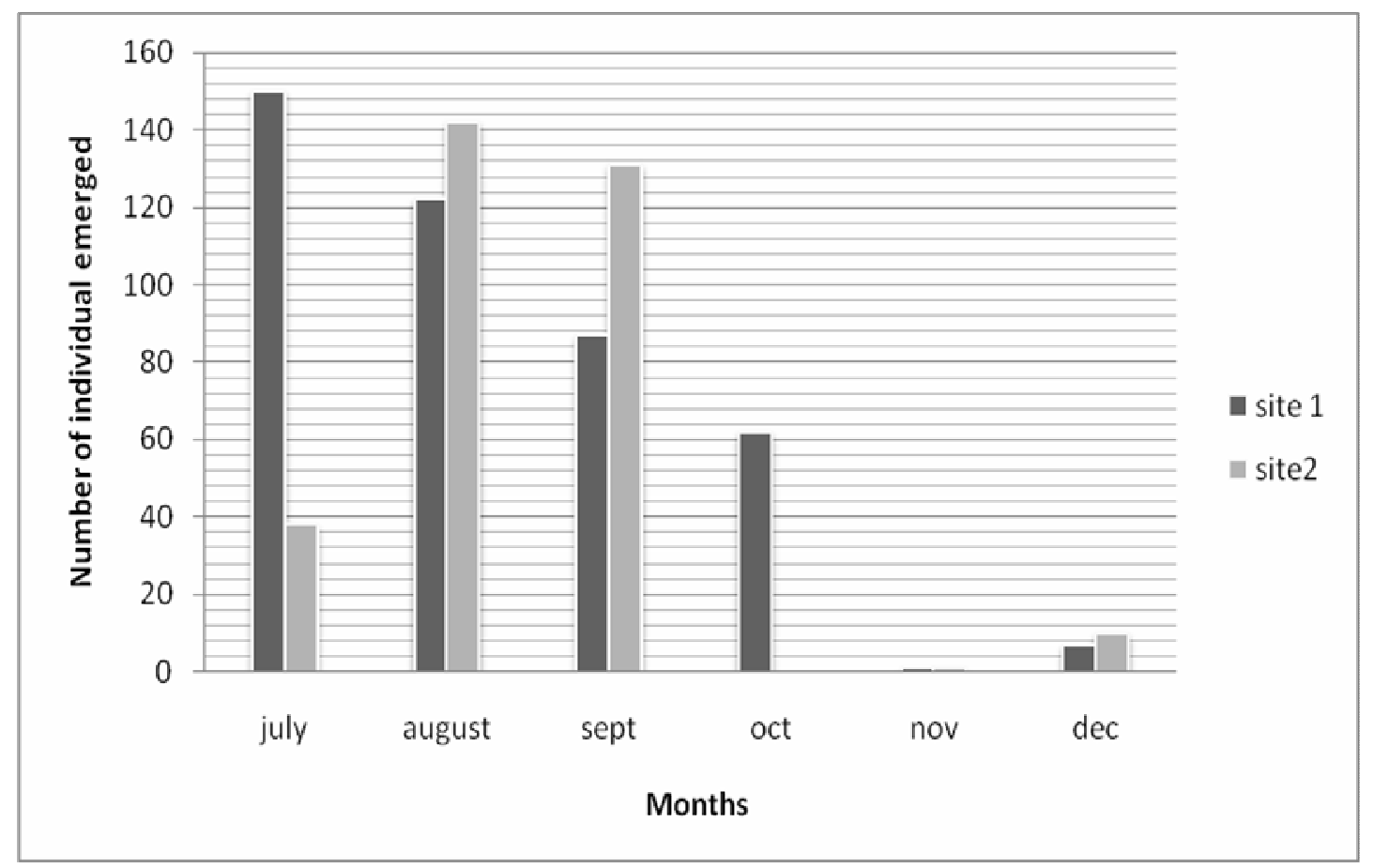

Figure 2: Monthly seedlings emergence densities in the rainy season in sites 1 and 2. 
Table 3: Comparison of species composition and similarity indices (based on Sorenson index) between the seed bank and the standing vegetation of the two study sites in dry and rainy seasons.

\begin{tabular}{|c|c|c|c|c|c|c|c|c|c|c|}
\hline & & & SITE 1 & & & & & SITE 2 & & \\
\hline Seasons & $\begin{array}{l}\text { No of } \\
\text { species in } \\
\text { the } \\
\text { standing } \\
\text { vegetation } \\
\text { (SV) }\end{array}$ & $\begin{array}{l}\text { No of } \\
\text { species } \\
\text { in Seed } \\
\text { bank } \\
\text { (SB) }\end{array}$ & $\begin{array}{l}\text { Species } \\
\text { common } \\
\text { to } \mathrm{SV} \\
\text { and } \\
\mathrm{SB}(\mathrm{CS})\end{array}$ & $\begin{array}{l}\text { Sorenson } \\
\text { Index of } \\
\text { similarity } \\
\text { between } \\
\text { SV and } \\
\text { SB }\end{array}$ & $\begin{array}{l}\text { Sorenson } \\
\text { Index of } \\
\text { similarity } \\
\text { of SB of } \\
\text { dry and } \\
\text { Raining } \\
\text { seasons }\end{array}$ & $\begin{array}{l}\text { No of } \\
\text { species in } \\
\text { the } \\
\text { standing } \\
\text { vegetation } \\
\text { (SV) }\end{array}$ & $\begin{array}{l}\text { No of } \\
\text { species } \\
\text { in Seed } \\
\text { bank } \\
(\mathrm{SB})\end{array}$ & $\begin{array}{l}\text { Species } \\
\text { common } \\
\text { to SV } \\
\text { and SB } \\
\text { (CS) }\end{array}$ & $\begin{array}{l}\text { Sorenson } \\
\text { Index of } \\
\text { similarity } \\
\text { between } \\
\text { SV and } \\
\text { SB }\end{array}$ & $\begin{array}{l}\text { Sorenson } \\
\text { Index of } \\
\text { similarity } \\
\text { of SB of } \\
\text { dry and } \\
\text { Raining } \\
\text { seasons }\end{array}$ \\
\hline $\begin{array}{l}\text { Dry } \\
\text { season }\end{array}$ & 23 & 27 & 13 & 48.1 & 72.4 & 17 & 22 & 8 & 34.8 & 61.9 \\
\hline $\begin{array}{l}\text { Rainy } \\
\text { season }\end{array}$ & 23 & 26 & 12 & 44.0 & 72.4 & 17 & 19 & 5 & 26.3 & 61.9 \\
\hline
\end{tabular}


Table 4: Seedling emergence in relation to the extent of the fallow land in the study sites 1 and 2 in both seasons.

\begin{tabular}{lccccccccccccc}
\hline \multicolumn{1}{c}{ Dry Season } & \multicolumn{1}{c}{ Rainy Season } \\
\hline Distance & $15 \mathrm{~m}$ & $30 \mathrm{~m}$ & $45 \mathrm{~m}$ & $60 \mathrm{~m}$ & $75 \mathrm{~m}$ & Total & $15 \mathrm{~m}$ & $30 \mathrm{~m}$ & $45 \mathrm{~m}$ & $60 \mathrm{~m}$ & $75 \mathrm{~m}$ & Total \\
Sites & & & & & & & & & & & & \\
& & & & & & & & & & & & \\
\hline Site 1 & 67 & 100 & 135 & 138 & 458 & 898 & 36 & 65 & 64 & 75 & 114 & 344 \\
& & & & & & & & & & & & \\
\hline Site 2 & 109 & 159 & 219 & 425 & 625 & 1536 & 68 & 41 & 75 & 25 & 100 & 309 \\
& & & & & & & & & & & & \\
\hline
\end{tabular}

However, for the rainy season sample in the study site 1, apart from Tithonia diversifolia, eleven (11) other species $(40.7 \%)$ were represented in both the standing vegetation and the seed bank and these were:

Andropogon gayanus, Bracharia deflexa, Chromolaena odorata, Euphorbia heterophylla, Euphorbia hirta, Mimosa pudica, Phyllanthus amarus, Spigella anthelmia, Talinum triangulare, Trema orientalis and Urena lobata. In the study site 2 , in the dry season samples, eight (8) out of the 23 species $(34.8 \%)$ that emerged from the seed bank had representatives in the standing vegetation apart from Tithonia rotundifolia which was dominant species. These species were: Andropogon gayanus, Bracharia deflexa, Desmodium scorparius, Ipomoea involucrata, Phyllantus amarus, Spigella anthelmia and Trema orientalis. 19 species emerged from the seed bank of study site 2 in the rainy season and only five (5) species $(26.3 \%)$ were represented in the standing vegetation and these species are: Andropogon gayanus, Bracharia deflexa, Phyllantus amarus, Spigella anthelma, Talinum triangulare and Trema orientalis.

Comparison of the species composition of the seed bank (SB) and the standing vegetation (SV) of the two study sites within seasons using Sorenson index of similarity (Table 3) revealed that the level of similarity was generally low and it ranged from $26.3 \%$ in the rainy season for site 2 to $48.1 \%$ in the dry season for site 1 . This result indicates that many of the species that emerged from seed bank were not represented in the standing vegetation. Furthermore, the species composition of the seed bank of each study site for the two seasons was subjected to similarity analysis and the result reveals a high level of similarity, $72.4 \%$ for Site 1 and $61.9 \%$ for Site 2 (Table 3).

\section{Seedling emergence in relation to extent of the fallowland \\ The result of the seedling emergence in} the 2 seasons and across the five distances shows that for site 1 (Ife-Ibadan), the least and the highest seedling densities were recorded in the $15 \mathrm{~m}$ and $75 \mathrm{~m}$ respectively inward away from the main road during the rainy season and the dry season (Table 4). Also for site 2 (Ife-Ilesa) the least and the highest seedling emergence came from $15 \mathrm{~m}$ and $75 \mathrm{~m}$ distances respectively during the dry season but the least and highest seedling emergence was observed in the $60 \mathrm{~m}$ and $75 \mathrm{~m}$ distances respectively during the rainy season. The total seedling emergence for each distance and for each site was pooled together and were subjected to two-way ANOVA, it shows a significant difference $(\mathrm{P}<0.01)$ in the seedling emergence density across the various distances. The seedling densities of the two sites were also subjected to Student's t-test. The result shows no significant change in seedling density between the two sites. 


\section{DISCUSSION}

The low level of similarity observed in the standing vegetation of the two study sites using the similarity analysis (Sorenson, 1948) may be a reflection of the difference in species composition of the sites. This observation agrees with the report of Chandrashekara and Ramakrishna (1993) that the level of disturbance and successional ages of forest have effects on species composition. The presence of few woody species most of which are secondary regrowth forest species may be as a result of annual burning that the sites are being subjected to. The road construction activities has led to the destruction of the existing forest cover and the consequent invasion of the sites by secondary successional species and herbaceous species respectively. Hall and Okali (1979) have observed that the presence or dominance of early successional species is an indication of disturbance. Furthermore, the general dominance of the seed bank of the two study sites by herbaceous species is in agreement with the reports of many workers (Oke et al., 2006; Oladipo and Oke, 2007).

The dominance of the soil seed bank by the seedlings of Tithonia diversifolia in site 1 as against site 2 is a reflection of the extent of human disturbance on both sites. Site 1 which is on a dual carriage road has recorded much more construction activities leading to more extensive open waste land in recent time than site 2 (a single lane) and consequently site 1 is more open to invasion by Tithonia diversifolia which Adebowale and Olorode (2005) described as having a wider spread across the ecological zones of Nigeria. Muoghalu and Chuba (2005) have also posited that Tithonia diversifolia species are plants of open sunny habitats. In agreement with Samuel et al. (2005) the spread of invasive Tithonia diversifolia in our local ecosystem leading to the replacement of native species/natural secondary fallow lands can potentially also account for the reduced number of seedlings of other species. The high rate of invasion by Tithonia species coupled with ease to colonize suitable open areas (like site 1) thus minimizing competition from other nearby plant species (Adebowale and Olorode, 2005). Also growth rate is said to be remarkably fast as well as forming closely packed populations that tend to choke out 'timid' competitors. A general lack of correspondence has also been reported for this study between the standing vegetation and the seed bank. Very few of the total species that emerged as seedlings in the seed bank were represented in the standing vegetation. The poor correlation between the above ground vegetation and the seed bank appears to be a general phenomenon. (Thompson and Grime, 1979 ; Staaf et al., 1987 ; Bekker et al., 2000). The exceptions are communities subjected to frequent disturbance selecting for annual lifeform and seed persistency (Melinda, 2004). Similarly, Oke et al. (2006) reported a large discrepancy between soil seed bank and standing vegetation. This phenomenon is reflected in this study and can be deduced that the potential of seed bank for restoration in fallow lands is low.

The seed bank density (5481-29615 seeds $/ \mathrm{m}^{2}$ ) reported for these Tithonia diversifolia dominated sites is comparable to the figures given by other workers for similar disturbed environments, for example Oke et. al. (2006) (6274-21872 seeds $\left./ \mathrm{m}^{2}\right)$, Oladipo and Oke (2007) (14115-21420 seeds $\left./ \mathrm{m}^{2}\right)$. However, the threat that the preponderance of Tithonia species posed to local flora, its reported production of phytotoxins or the allelopathic influence it has on neighbouring plant species (Ayeni et al., 1997) as well as its seed abundance in the seed bank has been observed as a factor that stabilizes Tithonia as a mono specific stand wherever it is found growing (Muoghalu and Chuba, 2005). This is possibly because it is capable of suppressing other species by outgrowing them (as tall as 5 $\mathrm{m})$ as well as the production of chemicals that inhibit the physiology of neighbouring species. The presence of Trema orientalis as the only woody species that emerged from the seed bank can be explained by the observation of Samuel et al. (2005) who have observed that invasive species pose a serious threat to native tree species because of the inhibiting effect that the extracts of the invasive species they used had on native tree seedlings. The effects of allelopathic/ phytotoxic influences of species like Tithonia may have important consequences for forest community composition (biodiversity) and succession over time (Samuel et al., 2005). Similarly, allelopathic interactions between plants have been implicated in the patterning 
of vegetation and weed growth in agricultural systems (Baruah and Sarma 1994). The increase in seedling density during the dry season could be ascribed to the fact that more wind dispersed seeds were deposited in sites during the dry season. The increase in seedling emergence inwardly away from the road sides in both study plots is an indication that Tithonia diversifolia which is an aggressive invasive plant suppresses the presence of other native species by outgrowing them at distances close to the main road where Tithonia spp density is higher. Hence, many other species seedlings were encountered at distances far away inwards from the main road where the influence of Tithonia was less. Akobundu and Agyakwa (1987) and Lordbanju (1991) reported similarly that $T$. diversifolia was found to be commonly associated with road sides, open and disturbed habitats and being absent from areas of mature plant establishments. The appearance and dominance of Chromolaena odorata (another early colonisers of waste lands) inwardly at distances more than $45 \mathrm{~m}$ is an indication that they are yet to be displaced by this invasive $T$. diversifolia at those distances.

Overall results suggest that the number of individuals and species that emerged from the soil seed bank may be due to the negative impact of $T$. diversifolia on other plant species and by their ability to produce abundance of seeds.

\section{REFERENCES}

Adebowale A, Olorode O. 2005. An overview of the invasive potential of Tithonia species (Asteraceae) in Nigeria. Science Focus, 10(3): 65-69.

Akobundu IO, Agyakwa CW. 1987. A Handbook of West African Weeds. International Institute of Tropical Agriculture: Oyo Road, Ibadan, Nigeria; $521 \mathrm{p}$.

Ayeni AO, Lordbanjou OT, Majek BA. 1997. Tithonia diversifolia (Mexican sunflower) in South- western Nigeria: Occurrence and growth habit. Weed Research, 37(6): 443-449.

Baruah NC, Sarma JC. 1994. Germination and growth inhibitory sesquiterpene lactones and a flavone from Tithonia diversifolia. Phytochemistry 36(1): 29-36.
Bekker RN, Gueurt LV, Jan PB, Latzi FM. 2000. Seed Bank Dynamics in Hay field Succession. Journal of Ecology, 88(4): 594- 607.

Bisteau E, Mahy G. 2004. Vegetation and Seed Bank in a calcacerous grassland restored from a Pinus forest. Applied Vegetation Science, 8: 167 - 174.

Chandrashekara UM, Ramakrishnan PS. 1993. Germinable Soil Seed bank dynamics during gap phase of a humid tropical forest in the Western Ghats of Keralla, India. Journal of Tropical Ecology, 9: 455-467.

Hall JB, Okali DUU. 1979. A structural and floristic analysis of woody fallow vegetation near Ibadan, Nigeria. Nigerian Journal of Ecology, 67: 321-346.

Howard MR, Hartemink AE. 2000. Soil Seed bank and Growth rates of an invasive species, Piper aduncum in the low land of Papua New Guinea. Journal of Tropical Ecology, 16: 243-251.

Hutchinson J, Dalziel JM. 1954-72. Flora of West Tropical Africa (2nd Edition by Keay RWJ and Hepper FN). Crown Agents for Overseas Government: London.

Lordbanju OT. 1991. Studies on Mexican sunflower (Tithonia diversifolia (hemsl.). A. Gray in Southwestern Nigeria. Unpublished M.Sc. Dissertation of the University of Ibadan, Ibadan.

Lorence DH, Suesman RW. 1986. Exotic species invasion into Mauritius wet forest remnants. Journal of Tropical Ecology, 2: 137- 162.

Melinda H. 2004. Crossingthe edge: Colonisation dynamics of fallow land in the sandy regions of Hungary. 16th International conference, Society for Ecological Restoration, August 24-26, 2004, Victoria, Canada.

Moughalu JI, Chuba DK. 2005. Seed germination and reproductive strategies of Tithonia diversifolia (Hemsl) and Tithonia rotundifolia (P.M Blake). Applied Ecology and Environmental Research. 3(1): 39-46.

Oke SO, Isichei AO. 1997. Floristic composition and structure of the fallow vegetation in Ile-Ife area of south western Nigeria. Nigerian Journal of Botany, 10: 37-50. 
Oke SO, Oladipo OT. Isichei AO. 2006. Seed bank dynamics and regeneration in a secondary lowland rainforest in Nigeria. International Journal of Botany, 2(4): 363-371.

Oladipo OT, Oke SO. 2007. Seed bank dynamics, seedling emergence and survival of herbaceous species in successional plots in Ile-Ife, south western Nigeria. Research Journal of Botany, 2(2): 76-85.

Pagad S, Browne M.2008. Invasive Species Drive Biodiversity Loss. Worldwatch Institute. http://www.worldwatch.org/ node/5473 [Accessed 13th April, 2009].

Raghubanshi AS, Rai LC, Gaur JP, Singh JS. 2005. Invasive alien species and biodiversity in India. Current Science, 88(4): 539-540.

Samuel OP, Jennifer AR, Keith C. 2005. Invasive plants can inhibit native tree seedlings: testing potential allelopathic mechanisms. Plant Ecology, 18: 153-165.

Staaf H, Johnson M, Olsen LG. 1987. Buried germinable seeds in mature beach forests with different herbaceous vegetation and soil types. Holaretic Ecology, 10: 268277.

Smyth AJ, Montgomery FR. 1962. Soil and Land use in central western Nigeria. The Government of Western Nigeria, Ibadan.

Sorenson T. 1948. A method of establishing groups of equal amplitude in a plant society based on similarity of species content. K. Danske Vidensk Selsk, 5: 134.

Thompson K, Grime JP. 1979. Seasonal Variation in the seed bank of herbaceous species in ten contrasting habitat. Journal of Ecology, 67: 893- 921. 